\title{
Are All Jobs Created Equal? A Cross-National Analysis of Women's Employment and Child Malnutrition in Developing Countries
}

\author{
Rebekah Burroway \\ Stony Brook University
}

Forthcoming in Social Science Research

This research was supported by a grant from the College of Arts and Sciences Dean's Fund for Excellence at Stony Brook University. Previous versions of this paper were presented at the annual meeting of the Sociology of Development in Salt Lake City, Utah; the winter meeting of the Sociologists for Women in Society in Santa Ana Pueblo, New Mexico; and the $61^{\text {st }}$ session of the Commission on the Status of Women in New York, New York. Please direct correspondence to Rebekah Burroway, Department of Sociology, Stony Brook University, Stony Brook, NY 11794. Email: rebekah.burroway@stonybrook.edu 


\title{
Are All Jobs Created Equal? A Cross-National Analysis of Women's Employment and Child Malnutrition in Developing Countries
}

\begin{abstract}
Using multi-level models, the analysis examines female employment and child stunting across 49 developing countries. At the country level, female labor force participation is not associated with malnutrition after controlling for economic development. At the individual level, a binary measure of employment is not significantly associated with malnutrition. However, a more nuanced measure of seven occupational categories shows that certain types of employment improve malnutrition. Professional, clerical, sales, and domestic jobs are associated with reduced stunting. These effects are only partially mediated by wealth, perhaps suggesting that some jobs may bring benefits to the household beyond the sheer acquisition of tangible resources. Agricultural jobs are associated with increased malnutrition. Manual labor and service work do not have an effect on malnutrition, compared to unemployment. Thus, women's employment is not necessarily a mechanism for empowerment and wellbeing. Not all jobs are created equal, and many of them do not confer the benefits that are typically associated with working outside the home.
\end{abstract}

Keywords: female labor force participation; women's employment; child malnutrition; developing countries; cross-national research; multi-level models 


\section{Are All Jobs Created Equal? A Cross-National Analysis of Women's Employment and Child Malnutrition in Developing Countries}

Globally, gender gaps in employment trended toward convergence until 2007, followed by a period of reversal from 2008 to 2012 during the economic crisis (ILO 2012). Gender gaps remain relatively unchanged since then in many parts of the world, while the gaps grow wider in others (ILO 2016). Although approximately 370 million women joined the labor market in the last two decades, women still comprise less than 40 percent of the work force globally (Verick 2014). And the chance for women to participate in the labor market remains about 27 percent lower than for men (ILO 2016).

Nonetheless, many scholars, policy makers, and development practitioners alike posit that women's employment is a key mechanism for enhancing health and wellbeing (e.g., Sen 1999; Diiro, Sam, and Kraybill 2016; IFC 2013; World Bank 2012). Improving women’s employment prospects has long been a goal of development agencies worldwide (Lamontagne, Engle, and Zeitlin 1998). World Bank President Jim Yong Kim underscores the broad-based benefits of promoting gender equality in the labor market: "We know that reducing gender gaps in the world of work can yield broad development dividends: improving child health and education, enhancing poverty reduction, and catalyzing productivity. Empowering women and girls is vital in order to achieve our twin goals: ending extreme poverty by 2030 and boosting shared prosperity" (World Bank 2014: foreword). Despite the persistent gender gaps in labor force participation, women's employment is heralded as a tool of both empowerment and development, particularly in poor countries. Given that women bear the primary responsibility for caregiving across many different cultural contexts (Duflo 2012), their empowerment has particularly substantial consequences for children. 
Yet, most recent research explores the impact that women's work has on children in the developed world (e.g., Morrill 2011; Wills and Brauer 2012; Bauer et al. 2012). While these studies generate important insights, the findings do not easily translate to developing country settings. For example, a large and growing body of research links maternal employment to child obesity in countries such as the United States, the United Kingdom, Canada, Australia, and the Netherlands (Morrissey 2013). Although the concern over child obesity is growing in developing countries, this is not the most pressing childhood problem for most. Almost one in four children are stunted worldwide (versus 6 percent who are overweight), and 90 percent of stunted children live in the developing world (UNICEF 2015). Understanding the patterns of inequality in child malnutrition not only affects children in the present, but it also has long-term consequences for the future. Adults who have suffered from malnutrition in childhood are less physically and intellectually productive (Blackwell, Hayward, and Crimmins 2001). This makes child malnutrition a fundamental underpinning of development in developing countries because it shapes how nations progress (UNICEF 2007).

But empirical evidence for the link between women's work and child malnutrition in developing countries is both limited and mixed (Mugo 2012). In country case studies, some find that maternal employment improves child malnutrition (Lamontagne, Engle, and Zeitlin 1998 [Nicaragua]; Diiro, Sam, and Kraybill 2016 [India]). Others find that employment increases the risk of malnutrition and infant death (Abbi et al. 1991 [India]; Basu and Basu 1991 [India]; Glick and Sahn 1998 [Guinea]), or that it is not statistically significant (Berman et al. 1997 [India]; Mugo 2012 [Kenya]). Still others report mixed results depending on the health outcome (Ukwuani and Suchindran 2003 [Nigeria]) or the gender of the child (Bhattacharya 2006 [India]). Cross-national studies are rare, but yield similarly contradictory results (e.g., Boehmer and 
Williamson 1996; Frongillo, de Onis, and Hanson 1997). Because of such inconsistent findings and the relative lack of developing country or cross-national analyses, there is still much we do not know about the effect of women's work on child health.

Thus, this analysis contributes to previous literature by examining the country-level influences on child malnutrition, as well as the household and maternal characteristics that impact malnutrition at the individual level. The study utilizes multi-level models that estimate the effects of female employment on within- and between-country variation in stunting among children under the age of 5 in 49 developing countries. Comparing women's status across countries is essential for capturing the structural conditions that shape gender stratification (Ghuman, Lee, and Smith 2006). Furthermore, multi-level models of women's employment are important for understanding wellbeing because the country-level variables capture the norms of the broader society and processes of institutionalization, while the individual-level variables tap into household processes and child socialization (Treas and Tai 2012). This technique suggests that child malnutrition is shaped by proximate variables, such as mother's employment or household wealth, but it is also shaped by the larger social context in which a child lives.

\section{WOMEN'S EMPLOYMENT, EMPOWERMENT, AND CHILD HEALTH}

Gender remains a salient source of social stratification worldwide, and inequalities between men and women are frequently linked to a wide range of demographic and health outcomes (Ghuman, Lee, and Smith 2006). Women's empowerment is touted as central to improving conditions for the next generation, since women's opportunities shape those of their children (World Bank 2011). Despite its frequent use, women's empowerment is an elusively defined refrain that is associated with many concepts (i.e., agency, autonomy, status, control, 
equality, freedom). Among the various definitions, there is some overlapping consensus on the key aspects of empowerment that are most central to improving wellbeing: resource control and decision-making (Malhotra and Schuler 2005; Desai and Johnson 2005).

Women's education is one of the most well-studied correlates of development and child health in the developing world (Bollen, Glanville, and Stecklov 2001) and is typically used as a proxy indicator for empowerment. This is, in part, because education fosters more opportunities for women to work outside the home (Nussbaum 2003). Yet, the large and growing scholarship on the consequences of women's education for child health far outweighs the scholarship on women's work in developing countries (Basu and Basu 1991). What has been missing from cross-national research is an investigation into whether women's work has the same positive benefits for children in developing countries that education does.

In theory, women's employment improves child health by giving them control over income, which subsequently enhances their status in society and increases their decision-making capacity in the household. Lisa C. Smith and colleagues (2003) stress that "employment is at the root of women's economic independence from men" (22). Indeed, economic power and control over resources may be the most important determinants of women's equality (McGuire and Popkin 1990). Such control over income is imperative for improving child health because women are more likely than men to use economic resources on basic family needs (Blumberg 1988; Hoddinott and Haddad 1995). Putting income under women's control raises household allocations toward food, nutrition, health, and education (Quisumbing 2003; Gummerson and Schneider 2013). Consequently, child survival probabilities increase significantly when income is controlled by mothers (Thomas 1990). Children's wellbeing depends critically on women's direct access to income, not income that is mediated through husbands or other male relatives 
(Agarwal 2003).

Gainful employment outside the home and the income that it brings, in turn, enhance the social status of women in the household and society (Pomeroy and Jacob 2004). Women become less dependent on others and their contribution to the prosperity of the family is move visible, giving them more bargaining power and greater influence in household decisions (Sen 1999). When women have greater autonomy in household decision-making, they are able to care for their children more effectively and efficiently. For example, the more freedom a woman has to make choices, the more likely she is to make timely decisions about using health services, treating and immunizing sick children, and following through on treatment recommendations (Smith et al. 2003). Working also brings women more freedom of movement and increased social contact with the world outside of the home, both of which expose them to new knowledge and behavior norms that could improve child health (Dharmalingam and Morgan 1996; Sen 1999; Smith et al. 2003).

Much empirical research corroborates the association between women's employment and their empowerment across multiple cultural contexts. For example, employment and/or control over income is associated with women's autonomy and decision-making power in Guatemala (Carter 2004), Mexico (Oropesa 1997), Sri Lanka (Malhotra and Mather 1997), India (Dharmalingam and Morgan 1996), Bangladesh (Hashemi, Schuler, and Riley 1996), Nepal (Acharya et al. 2010), Nicaragua and Peru (Heaton et al. 2005a). These are just a few examples of the breadth of scholarship in this area. The relationship between women's empowerment and child health is also well documented (e.g., Shroff et al. 2009; Richards et al. 2013; Imai et al. 2014; Burroway 2016). Despite a large literature on work and empowerment and another large literature on empowerment and health, fewer studies bridge these two areas of research. The 
summary of findings from empirical research on women's work and child health in the developing world are not as clear. In some countries, women's employment improves child malnutrition as expected (e.g., Shuhaimi and Muniandy 2012), but in others it appears to have adverse consequences (e.g., Toyoma et al. 2001; Maddah et al. 2007).

Outside employment may have contradictory effects on child health because it reduces the time available for childcare (Bhattacharya 2006; Smith et al. 2003). Market child-care substitutes are often unavailable in rural areas or unaffordable in urban areas. Thus, mothers have to rely on relatives or older children who may not provide the same quality of care that the mother would (McGuire and Popkin 1990; Lamontagne, Engle, and Zeitlin 1991). Working mothers may also lack the time to adequately prepare nutritious food or make use of public services that are designed to improve child health (Glick and Sahn 1998). In addition, it is possible that female employment in developing countries reflects their impoverishment, not their greater autonomy (Drovandi and Salvini 2004; Young 2001). In poor countries, large numbers of women working may be driven by poverty and is a response to crisis or economic shocks (Verick 2014). Thus, the child health effects of women's work remain ambiguous. Women's work can generate more income, which translates into more spending on food and health, but women's work can also reduce the quantity and quality of childcare (Ukwuani and Suchindran 2003; Diiro, Sam, and Kraybill 2016). The pattern of findings is mixed and often contradictory, and the literature on this topic has not kept pace with the modern realities of women's work in the developing world (see Glick 2002 and Leslie 1988 for reviews).

In theory, then, employment enhances women's access to income and augments their decision-making capacity in the household, both of which may plausibly improve child health. But in addition to such household relations, it is important to consider women's employment in a 
larger context as well (Treas and Tai 2012). For example, a comparison of two villages in southern India shows that the principal determinant of a woman's autonomy is not whether she is employed herself, but whether she lives in a village where a majority of women are employed. Employment opportunities institute new social norms at the macro level that provide leverage for women to renegotiate relationships with men at the individual level (Dharmalingam and Morgan 1996). Thus, in this analysis, living with a mother who works and living in a larger social context in which many women work are both treated as explanatory variables that may affect child malnutrition.

One limitation of previous research is that the nature of women's employment is frequently unaddressed. That is, employment is often measured as a binary variable that indicates whether a mother is employed or unemployed (e.g., Abbi et al. 1991; Basu and Basu 1991; Diiro, Sam, and Kraybill 2016). Very few studies go beyond this dichotomy. When researchers do consider type of employment, they typically categorize work as formal or informal (Glick 2002). But, such simplistic measures of employment obscure the fact that not all jobs yield the same benefits, or lack thereof. Even in countries with close to gender parity in labor participation rates, the quality of employment opportunities is unequally distributed between men and women (Verick 2014). Women are disadvantaged in terms of wages and training and tend to be overrepresented in temporary, part-time, informal work. When they are incorporated into the global economy, they are often exploited as a source of cheap labor (Moghadam 1999; Mehra and Gammage 1999). For this reason, an examination of the different types of occupations that women take on in the developing world is imperative for understanding how their work influences wellbeing. This study fills an important gap in the literature on women's work and health by conceptualizing work not just as a broad dichotomous variable, but also as a series of 
categorical variables that specify occupation more precisely. Another limitation of previous

research is that many frequently cited studies are more than a decade, or even more than two decades, old. This is problematic insofar as it suggests that some questions may be prematurely regarded as answered. Much of the literature on women's education, employment, and empowerment is repeatedly cited rather than being continually investigated. Yet, there is still much that is unknown about what empowerment means and whether and how it translates into better wellbeing.

\section{METHODS}

\section{Data and Sample}

Individual-level data (level 1) are drawn from the Demographic and Health Surveys (DHS), a collection of nationally representative, population-based surveys conducted in developing countries (Macro 2009). ${ }^{1}$ Data on country-level variables are collected from the World Development Indicators database (World Bank 2010). The sample includes countries with available data on the dependent variables collected during DHS phases 3 through 5 (1995-2008) for comparability in time and content. Thus, the analysis pools data on 275,872 children under the age of 5 in 49 developing countries. ${ }^{2}$ (See Appendix 1 for a list of countries included in the

\footnotetext{
${ }^{1}$ The DHS program rigorously trains their staff and closely supervises them in the field. As a result, the majority of households identified in DHS sampling procedures are successfully interviewed. The average household response rate across several phases of the survey is 97 percent (Vaessen, Thiam, and Lê 2005).

${ }^{2}$ The study sample represents a range of least developed (e.g., Democratic Republic of the Congo and Niger) to middle income (e.g., Gabon and Brazil) countries from all over the world. Comparing the analytic sample to the larger population of developing countries shows that the sample is very comparable to other low and lower middleincome countries in average GDP per capita, female school enrollment, and female employment.

${ }^{3}$ A number of other variables are often included in cross-national research on child health. The decision to omit additional control variables from level 2 is based on data availability, multicollinearity, and parsimony. Missing data on income inequality, social welfare expenditures, and public health expenditures reduce the sample size by 5

${ }^{2}$ The study sample represents a range of least developed (e.g., Democratic Republic of the Congo and Niger) to middle income (e.g., Gabon and Brazil) countries from all over the world. Comparing the analytic sample to the larger population of developing countries shows that the sample is very comparable to other low and lower middleincome countries in average GDP per capita, female school enrollment, and female employment.
} 
analysis.) 


\section{Estimation Technique}

Hierarchical generalized linear logit models (HGLM) predict the odds that a child is malnourished based on a set of both individual- and country-level explanatory variables. The analysis is executed using the HLM 6.08 software developed by Raudenbush and colleagues (2004). This is a common modeling technique for cross-national analyses with a nested data structure and dichotomous dependent variables (e.g., McTavish et al. 2010; Givens and Jorgenson 2013; Burroway 2016; Magadi 2011). The advantage of this technique is that the net effects of one level can be estimated while controlling for variation in the other level. Ignoring the nesting of observations within clusters violates the assumption of independent standard errors and inflates the risk of a Type 1 error. However, hierarchical analysis provides unbiased and efficient estimates of the coefficients, as well as proper standard error estimates (Guo and Zhao 2000; Raudenbush and Bryk 2002).

One limitation of multi-level models is that they do not control for unobserved countrylevel factors in the same manner as a traditional fixed effects model. This is problematic because omitted group-level variables can potentially bias the individual-level slope estimates (Chaplin 2003). One solution to this problem is group-mean centering: individual-level variables are differenced from their country means at level 1 . This produces the most accurate slope estimates for the individual level variables, even in the presence of unobserved country-level variables that are correlated with the individual-level variables (Chaplin 2003; Raudenbush and Bryk 2002). Group-mean centering also has a theoretical advantage. It implies that an individual's relative position within a country influences the outcome. This is appropriate for cross-country comparisons in which levels of wealth or education, for example, may have different value depending on context (Enders and Tofighi 2007). Correlation matrices (not shown but available 
upon request) suggest that multicollinearity is not a problem in this analysis. Histograms are employed to examine the distribution of variables, and the natural log is used to correct for skewness when a variable violates the assumption of normality (details below). Finally, the models are estimated with robust standard errors to correct for heteroskedasticity (Raudenbush et al. 2004).

\section{Variables}

The dependent variable is a binary indicator of child malnutrition that is calculated using anthropometric measures of height and weight. Stunting is defined as low height-for-age. A child is coded as stunted if s/he is more than two standard deviations below the median of the World Health Organization child growth standards for his/her height, age, and gender (WHO 2006). Stunting results from prolonged or recurrent food deprivation or illness and is therefore an indicator of chronic malnutrition (UNICEF 2015). It can also be caused by low birth weight, inadequate care, or frequent infections. Stunting is widely accepted as the best measure of inequality in child wellbeing because it captures multiple dimensions of health, development, and the context in which children live (Wamani et al. 2007). Moreover, this measure is used in other studies of women's employment and child malnutrition in developing countries (e.g., Frongillo, de Onis, and Hanson 1997; Glick and Sahn 1998; Mugo 2012).

At the country level, women's employment is assessed by the female labor force participation rate. This measure is expressed as a percentage of the female population over age 15. As is standard in cross-national analyses, economic development is included in order to ensure that the effects of women's employment are independent of a country's level of prosperity. Economic development is measured as gross domestic product (GDP) per capita in purchasing power parity dollars, logged to correct for its highly skewed distribution. Economic 
development improves child malnutrition by increasing the food supply, medical technology, and overall standards of living (Jenkins and Scanlan 2001; Coburn, Restivo, and Shandra 2015). Because women's education is the most common proxy for women's empowerment in crossnational research (Burroway 2015), the models include gross female secondary school enrollment as a percentage of age appropriate children. Previous research shows that this variable is associated with reduced child malnutrition across developing countries (e.g., Smith et al. 2003; Burroway 2016). ${ }^{3}$

At the individual level, maternal employment is measured in two ways. First, mother employed is a dichotomous variable, coded as 1 for currently employed and 0 for unemployed. Although this is a common measurement strategy, it conceals the variation in employment. Different types of work come with various costs or benefits, and may therefore affect child malnutrition in different ways. For this reason, the models also include a more nuanced series of 7 occupational categories, including professional/technical/managerial, clerical, sales, household/domestic, services, manual, and agriculture (with unemployed as the omitted reference group). ${ }^{4}$

Household wealth and maternal education are the two most well-studied correlates of child health in developing countries at the individual level (Bollen, Glanville and Stecklov

\footnotetext{
${ }^{3}$ A number of other variables are often included in cross-national research on child health. The decision to omit additional control variables from level 2 is based on data availability, multicollinearity, and parsimony. Missing data on income inequality, social welfare expenditures, and public health expenditures reduce the sample size by 5 or more countries. Given that there are only 49 countries, this is a substantial reduction and greatly reduces the statistical power at level 2. Urbanization was added in additional analysis not shown, but the models would not converge due to singularity. Urbanization is highly collinear with economic development $(r=.77)$. Access to sanitation and water is similarly problematic because this variable is highly collinear with female school enrollment $(\mathrm{r}=.86)$. International trade, democracy, political regime stability, and military expenditures are not significantly associated with child malnutrition in these models. Given that the relatively small sample size of countries restricts the number of predictor variables that can be added at level 2, these variables are omitted for parsimony. ${ }^{4}$ DHS provides information on women who indicate that they are agricultural employees or self-employed in agriculture. Additional analysis using the two agriculture variables separately yields comparable results to those presented here. Thus, agriculture is collapsed into one category for parsimony. Similarly, DHS provides data on skilled versus unskilled manual labor. Consistent with the results presented here, neither variable is significant when added to the models separately, so skilled and unskilled are collapsed into one category of "manual labor."
} 
2001). Household wealth is measured as a composite index that represents the cumulative living standard of a household. Following previous research (Heaton et al. 2005b), this index is calculated as the percentage of household items (including clean water, flush toilet, radio, television, electricity, refrigerator, bicycle, motorcycle, car, telephone, and finished floor) present in the home. ${ }^{5}$ Wealthier families are better able to provide health care, medication, appropriate food, and a clean, safe place to live (Heaton et al. 2005b). Mother's education is measured as a series of categorical variables including primary, secondary, and higher, with no education as the reference group. On a basic level, maternal education improves child malnutrition through general access to information and greater health knowledge (Thomas, Strauss, and Henriques 1990). But beyond this, education strengthens bargaining power in the home and puts women in a better position to make decisions regarding childcare (Nussbaum 2003).

Several additional variables are included in all models as controls. A dichotomous variable indicates the presence of a female household head (coded as 1 for yes and 0 for no). Female headed households are more likely to experience poverty than other households (Buvinic and Gupta 1997), which suggests that they are at greater risk for child malnutrition as well. However, given that women are more likely than men to prioritize nutrition (Smith et al. 2003), female headship could also reduce the odds of malnutrition. Household size is measured as total number of persons living in the household. A child's nutrition can be compromised in large families where resources are shared among many and competition for food is greater (LeGrand and Phillips 1996; Heaton et al. 2005b). Urban residence is included as a binary variable, coded

\footnotetext{
${ }^{5}$ Asset-based measures are widely used to indicate socioeconomic status because very few demographic surveys gather data on income or consumption expenditures in developing countries (Montgomery et al. 2000; Bollen, Glanville and Stecklov 2001). Previous research shows that asset-based measures are a consistent proxy for income (Corsi et al. 2012), and some scholars even suggest that they are superior to income in developing country contexts (Jones-Smith et al. 2012).
} 
1 for urban and 0 for rural. Cities provide more access to milled grains, animal products, and other foods that enhance energy and fat density (Popkin 1999). Child's age (measured in months) and child's sex (coded as 1 for male, 0 for female) are also included. Although newborns in poor countries are often underweight compared to their more affluent counterparts, newborn lengths are actually similar. Growth retardation generally occurs between 3 and 18 months, but perhaps even into the third year or longer (Martorell, Khan, and Schroeder 1994). Thus, because the dependent variable measures length/height, the odds of stunting may increase with age. Apart from studies in Asia that occasionally report higher female vulnerability, many other studies of low-income countries find that males are more likely to be stunted (Wamani et al. 2007). Finally, mother's age is measured in years. Maternal age is associated with better child health because older mothers are healthier themselves and tend to have higher levels of educational attainment (Sutcliffe et al. 2012; Barclay and Myrskyla 2016). ${ }^{6}$ Descriptive statistics for all variables in the analysis are provided in Appendix 2.

\section{RESULTS AND DISCUSSION}

Figure 1 shows the correlation between female labor force participation and stunting prevalence at the country level. Contrary to the expectation that women's employment should be associated with lower rates of child malnutrition, the relationship is slightly positive $(r=.27)$. That is, women's employment correlates with slightly higher rates of child stunting. However, it

\footnotetext{
${ }^{6}$ The regression models omit father's characteristics for methodological and theoretical reasons. First, in order to facilitate the analysis of data, DHS develops recode files with standard data definitions across countries and DHS phases. Because the unit of analysis is the child, the appropriate dataset for this study is the "children's recode." The children's recode includes extensive data on the mother, however, data on the father are far more limited. Perhaps more importantly, the omission of fathers is in keeping with the tradition of a substantial body of literature on child wellbeing in developing countries that concentrates solely on women's characteristics (e.g., Abbi et al. 1991; Burroway 2016; Bhattacharya 2006; Frongillo et al. 1997; Kravdal 2004; Shroff et al. 2009). The focus on women is particularly salient because women typically bear the primary responsibility for caregiving and maintaining household food security, and because they are more likely than men to use economic resources on child nutrition (Burroway 2015).
} 
is important to note that among the 15 countries with the highest rates of women's employment, 10 are also among the poorest countries in the sample (Mozambique, Ethiopia, Malawi, Central African Republic, Rwanda, Madagascar, Uganda, Burkina Faso, Tanzania, and Guinea). This suggests that employment may not be a reflection of empowerment, but rather a reflection of extreme disadvantage. Higher rates of women's employment may be indicative of poverty and the imperative need to work, not women's autonomy. This also underscores the need to examine the distribution of different types of employment within countries in order to fully understand how women's work affects their children.

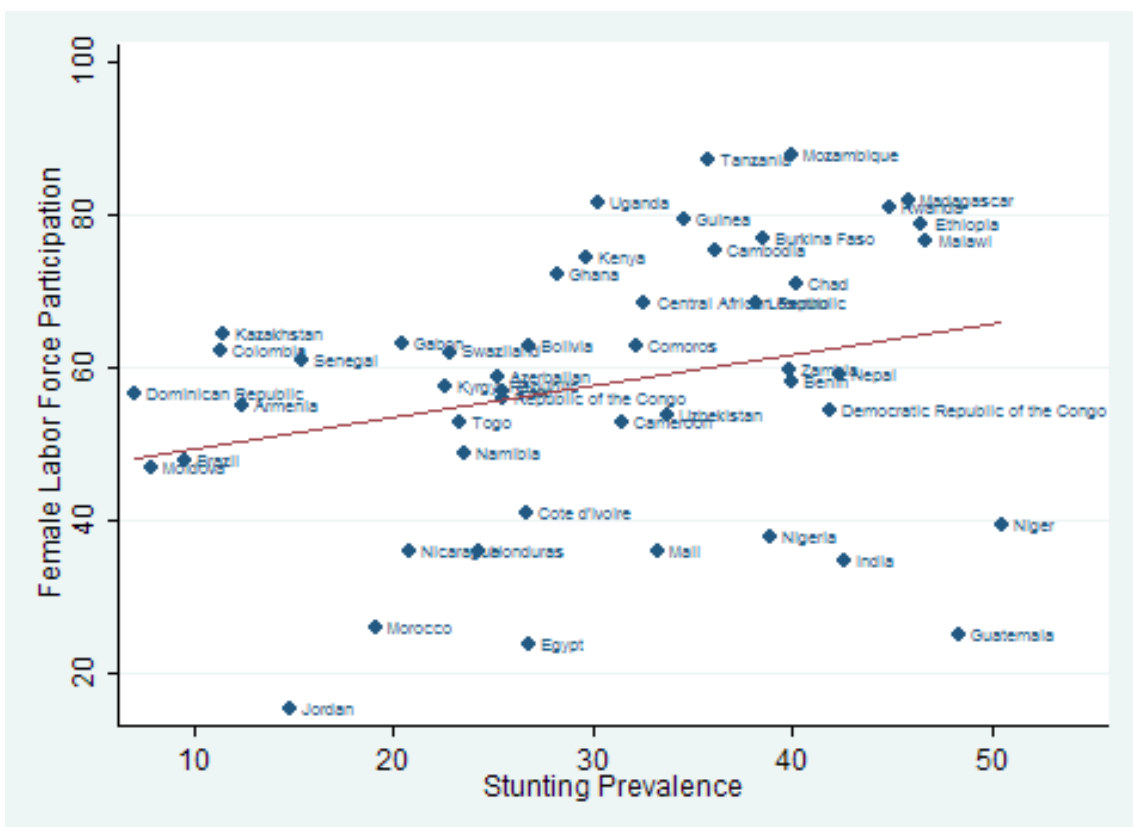

Figure 1. Correlation between Female Labor Force Participation Rate and Stunting Prevalence $(r=.27)$

Tables 1-2 display the results for HGLM models that predict the odds of childhood stunting. Beginning with Table 1, Model 1 shows the bivariate relationship between female labor force participation and stunting at the country level. Model 2 adds GDP per capita in order to determine whether economic development explains the relationship between women's 
employment and malnutrition, as suggested by Figure 1. Model 3 adds female secondary school enrollment. The individual-level variables are similarly sequenced in Table 1, and all of the models control for other relevant household characteristics. Table 2 examines women's employment as occupational categories. Model 1 presents seven different types of women's work. Because economic resources are the key mechanism linking employment to child health, Model 2 adds household wealth to examine possible mediating effects. Table 2 includes all of the same individual-level variables displayed in Table 1. They are not shown for the sake of parsimony, but the results are consistent across models.

Table 1. HGLM Models of Women's Employment and Child Malnutrition

\begin{tabular}{|c|c|c|c|}
\hline & Model 1 & Model 2 & Model 3 \\
\hline \multicolumn{4}{|l|}{ Country Level $(N=49)$} \\
\hline \multirow{2}{*}{ Female Labor Force Participation } & $1.010 *$ & 0.999 & 0.997 \\
\hline & 2.162 & -0.276 & -0.732 \\
\hline \multirow[t]{2}{*}{ GDP per capita } & & $0.579 * * *$ & $0.727 * *$ \\
\hline & & -5.699 & -2.936 \\
\hline \multirow[t]{2}{*}{ Female Secondary School Enrollment } & & & $0.991 *$ \\
\hline & & & -2.421 \\
\hline \multicolumn{4}{|l|}{ Individual Level $(N=275,872)$} \\
\hline \multirow[t]{2}{*}{ Female Household Head } & 0.987 & $0.926 * * *$ & $0.946 * * *$ \\
\hline & -0.702 & -4.805 & -3.559 \\
\hline \multirow[t]{2}{*}{ Household Size } & $1.009 *$ & $1.020 * * *$ & $1.105 * * *$ \\
\hline & 2.001 & 4.149 & 3.491 \\
\hline \multirow[t]{2}{*}{ Urban Residence } & $0.532 * * *$ & $0.849 * *$ & $0.876 * *$ \\
\hline & -9.386 & -2.783 & -2.658 \\
\hline \multirow[t]{2}{*}{ Child's Age } & $1.026 * * *$ & $1.027 * * *$ & $1.027 * * *$ \\
\hline & 21.253 & 21.213 & 20.853 \\
\hline \multirow[t]{2}{*}{ Male } & $1.176 * * *$ & $1.183 * * *$ & $1.185 * * *$ \\
\hline & 4.989 & 5.429 & 5.399 \\
\hline \multirow[t]{2}{*}{ Mother's Age } & $0.995 * *$ & $0.994 * * *$ & $0.992 * * *$ \\
\hline & -2.596 & -3.809 & -5.128 \\
\hline \multirow[t]{2}{*}{ Mother Employed } & 1.004 & 0.984 & 0.983 \\
\hline & 0.071 & -0.636 & -0.764 \\
\hline
\end{tabular}




\begin{tabular}{lcc} 
Household Wealth & $0.979^{* * *}$ & $0.983^{* * *}$ \\
& $\mathbf{- 1 8 . 0 3 6}$ & $\mathbf{- 1 5 . 0 4 5}$ \\
Mother's Education & \\
Primary & $0.831^{* * *}$ \\
& $\mathbf{- 5 . 3 1 8}$ \\
Secondary & $0.629^{* * *}$ \\
& -7.332 \\
Higher & $0.467^{* * *}$ \\
\hline
\end{tabular}

Notes: $* \mathrm{p}<.05 \quad * * \mathrm{p}<.01 \quad * * * \mathrm{p}<.001$ (two-tailed tests)

Each cell contains odds ratios and t-scores in bold and italics.

Starting with the country-level results of Table 1, the odds ratio for female labor force participation is significant and positive in Model 1. Mirroring the graphic pattern in Figure 1, women's employment is associated with increased malnutrition. However, when Model 2 adds GDP per capita, the effect of female labor force participation attenuates to insignificance. When level of economic development is held constant across countries, female labor force participation does not have a significant association with the odds of stunting. The initial positive relationship between employment and malnutrition is explained by GDP. This provides some suggestive evidence that in many developing countries with high rates of women's employment, poor women are forced to work out of economic necessity. So their children's poor nutrition status is mostly due to low income (Abbi et al. 1991). When income is held constant across countries, the adverse effect of women's employment goes away. Model 3 shows that female secondary school enrollment is significantly associated with lower odds of stunting, which is in line with previous research. Thus, children are at less risk of malnutrition when they live in a context in which many women are educated, regardless of whether many women are employed.

At the individual level, Table 1 shows that children of employed mothers have no difference in the odds of stunting than children of unemployed mothers (Model 1). The effect of mother's employment remains insignificant after adding household wealth (Model 2) and 
maternal education (Model 3) into the models. Paralleling the results at the country level, wealth and education are significantly associated with lower odds of stunting. Moreover, the effect of education grows stronger in magnitude with every level of achievement, from primary to secondary to tertiary. As expected, older mothers, female headed households, and urban households are associated with a decline in the risk of stunting. Older children, male children, and children living in larger households are at increased risk of stunting.

Table 2. HGLM Models of Women's Occupational Categories and Child Malnutrition

\begin{tabular}{|c|c|c|}
\hline & Model 1 & Model 2 \\
\hline \multicolumn{3}{|l|}{ Country Level $(N=49)$} \\
\hline \multirow[t]{2}{*}{ Female Labor Force Participation } & 0.997 & 0.997 \\
\hline & -0.789 & -0.737 \\
\hline \multirow[t]{2}{*}{ GDP per capita } & $0.723 * *$ & $0.727 * *$ \\
\hline & -3.001 & -2.933 \\
\hline \multirow[t]{2}{*}{ Female Secondary School Enrollment } & $0.991 *$ & $0.991 *$ \\
\hline & -2.407 & -2.422 \\
\hline \multicolumn{3}{|l|}{ Individual Level $(N=275,872)$} \\
\hline \multirow[t]{2}{*}{ Professional, Technical, Managerial } & $0.742 * * *$ & $0.796 * *$ \\
\hline & -7.319 & -3.095 \\
\hline \multirow[t]{2}{*}{ Clerical } & $0.580 * * *$ & $0.661 * * *$ \\
\hline & -4.485 & -3.951 \\
\hline \multirow[t]{2}{*}{ Sales } & $0.850 * * *$ & $0.889 * * *$ \\
\hline & -5.740 & -4.623 \\
\hline \multirow[t]{2}{*}{ Household and Domestic } & $0.888 * *$ & $0.896^{*}$ \\
\hline & -2.772 & -2.462 \\
\hline \multirow[t]{2}{*}{ Services } & 0.959 & 0.986 \\
\hline & -0.655 & -0.276 \\
\hline \multirow[t]{2}{*}{ Manual } & 0.969 & 0.977 \\
\hline & -0.895 & -0.863 \\
\hline \multirow[t]{2}{*}{ Agriculture } & $1.127 * * *$ & 1.059 \\
\hline & 3.720 & 1.900 \\
\hline \multirow[t]{2}{*}{ Household Wealth } & & $0.983 * * *$ \\
\hline & & -15.239 \\
\hline
\end{tabular}

Notes: $* \mathrm{p}<.05 \quad * * \mathrm{p}<.01 \quad * * * \mathrm{p}<.001$ (two-tailed tests)

Each cell contains odds ratios and t-scores in bold and italics. 
The models also include individual-level controls for female headed household, household size, urban residence, child's age, child's gender, mother's age, and mother's education.

Table 2 divides mother's employment into 7 occupational categories (with unemployed mothers at the omitted reference group). Model 1 shows that some occupations are protective of health, others are harmful, and still others have no substantial impact. Employment in professional, clerical, sales, or domestic jobs is significantly associated with reduced odds of stunting. Agricultural work, however, is associated with an increase in the odds of stunting. This finding is of particular importance since agricultural work is by far the largest occupational category. Approximately 28 percent of the women in the sample reports that they work in agriculture (Appendix 2). This is compared to 16 percent who work in professional, clerical, sales, and domestic jobs combined. Manual or service work has no significant relationship with child malnutrition. Women who work in these industries account for about 10 percent of the sample. Thus, only a small percentage of children are reaping health benefits from their mother's work. Such differences among occupations underscore the importance of a more detailed examination of women's employment, since aggregate measures do not tell the full story.

Model 2 of Table 2 adds household wealth. The effects of professional, clerical, sales, and domestic work remain robustly significant, although the magnitude of the effects diminish in size slightly. This may suggest that part of the way in which certain occupations benefit child health is through the acquisition of economic resources. Jobs in professional, clerical, sales, and domestic industries bring more income and assets to women that subsequently allow them to invest in the needs of their children. However, the effects of these occupations are not entirely mediated by wealth. That is, certain occupations bring benefits to children above and beyond the benefits wrought by more household wealth. On the other hand, the effect of agricultural 
employment greatly attenuates in size and strength with the addition of wealth. Agricultural employment is very close to significant at the .05 level in Model $2(t=1.9$ in a two-tailed test $)$. Perhaps agricultural employment does not bring the same economic returns as other occupations, and this may explain why such jobs are not as beneficial for child health.

\section{CONCLUSION}

Of course, cross-national data for developing countries remain imperfect. The analysis includes a range of developing countries (see footnote 2), but caution may be warranted in generalizing to countries outside of the analytic sample used here. Despite the directionality of

the hypotheses drawn from previous research, the cross-sectional nature of the data cannot prove causality. This limitation may be overcome in time as DHS data collection continues. Women's labor force participation tends to be underestimated (Verick 2014), which could also potentially bias the results. However, given that women tend to be overrepresented in industries that undermine their self-efficacy and potential (World Bank 2012), the results presented here are most likely conservative.

Further research is needed to fully understand what it means to be "employed" in agriculture. Rural livelihoods in developing countries are incredibly diverse due to variation in human capital, seasonality, markets, infrastructure, access to credit, and farm size. Thus, some farmers engage in multiple income-generating activities and rely on a diverse income portfolio (Ellis 2000). Women may work on their own separate plot or in joint enterprises with others in the household. They may have control over homestead gardens, or they may migrate to other places in search of agricultural labor opportunities. They may raise cash crops to sell in local markets, or they may work in modern, high-value agribusiness (Quisumbing et al. 2014). DHS 
data are limited by their inability to parse out such differences. Further research is also necessary to understand the mechanisms by which women's work affects child health. Again, DHS data are limited in this respect. More detailed information on income or other nonwage benefits would help clarify exactly why and how occupations affect child health.

In spite of the limitations, the analysis suggests that women's employment is a not a guaranteed solution to the pressing child health problems that developing countries face today. Some types of women's employment do improve child wellbeing by reducing malnutrition. Work in professional, clerical, sales, or domestic jobs is associated with lower risk of child malnutrition. This is true even controlling for wealth, perhaps indicating that some types of women's employment may benefit the family over and above the resultant financial contributions. However, women's employment is not necessarily a mechanism for empowerment and better family wellbeing in developing countries. Not all jobs are created equal, and many of them do not confer the advantages that are typically associated with working outside the home. Agricultural workers are particularly disadvantaged. They seldom own the land they cultivate, they are vulnerable to poverty and gender discrimination, and they have few other options due to their residence in rural areas (Agarwal 2003; Pomeroy and Jacob 2004). Engaging in vulnerable employment doesn't empower women. It is merely a reflection of their subordinate position in the household and in society (Verick 2014). Given that agricultural workers comprise the largest occupational category in the sample, this has important implications for child health.

Reducing barriers to employment is imperative for lifting women out of poverty (Quisumbing, Hallman, and Ruel 2007). And increased labor market opportunities for women can have transformative effects on households, leading to more equal treatment of girls and women (Duflo 2012). But, promoting female employment will not necessarily have positive 
effects on child health if vulnerabilities in women's work are not addressed. A variety of formal and informal institutional structures shape the ability of women to enter the labor force, as well as the benefits that they derive once they do so. In many countries, policies that regulate market work impose restrictions on women that curtail their ability to fully benefit from the world of work. Furthermore, women earn less than men on average and tend to be overrepresented in industries that undermine their self-efficacy and potential (i.e., agriculture) (World Bank 2012; Verick 2014).

The results of this analysis suggest that policies are needed to not only remove women's barriers to labor force participation, but also to improve their representation in occupations that can truly have transformative consequences for the lives of women and their children. Ensuring access to quality education is perhaps one of the most critical ways in which to improve women's employment outcomes (Verick 2014). And policies that are meant to promote maternal work need to also offset the risks that are associated with work, like hazardous working conditions or lack of adequate childcare substitutes (Diiro, Sam, and Kraybill 2016; Glick and Sahn 1998). At all income levels and in many different cultural contexts, women perform the majority of childcare (Duflo 2012). Thus, scarcity of and high prices for childcare limit the employment options for women and decrease their earnings potential (Quisumbing, Hallman, and Ruel 2007). Employment does not guarantee empowerment, but certain types of jobs can potentially help women provide better health for their children. The challenge that lies ahead is to help women gain access to good jobs as countries grow and develop (Verick 2014). 


\begin{tabular}{ll} 
Appendix 1. Analytic Sample & \\
\hline Armenia & Kenya \\
Azerbaijan & Kyrgyz Republic \\
Benin & Lesotho \\
Bolivia & Madagascar \\
Brazil & Malawi \\
Burkina Faso & Mali \\
Cambodia & Moldova \\
Cameroon & Morocco \\
Central African Republic & Mozambique \\
Chad & Namibia \\
Colombia & Nepal \\
Comoros & Nicaragua \\
Cote d'Ivoire & Niger \\
Dem. Republic of the Congo & Nigeria \\
Dominican Republic & Peru \\
Egypt & Republic of the Congo \\
Ethiopia & Rwanda \\
Gabon & Senegal \\
Ghana & Swaziland \\
Guatemala & Tanzania \\
Guinea & Togo \\
Honduras & Uganda \\
India & Uzbekistan \\
Jordan & Zambia \\
Kazakhstan & \\
\hline
\end{tabular}


Appendix 2. Descriptive Statistics

\begin{tabular}{lrrrr}
\hline & Mean & St. Dev. & Min & Max \\
\hline Country Level (N=49) & & & & \\
Female Labor Force Participation & 57.59 & 17.56 & 15.50 & 87.70 \\
GDP per capita & 7.54 & 0.85 & 5.66 & 9.49 \\
Female Secondary School Enrollment & 44.53 & 30.08 & 5.48 & 104.35 \\
& & & & \\
Individual Level (N=275,872) & & & & \\
Stunted & 0.32 & 0.47 & 0.00 & 1.00 \\
Mother Employed & 0.56 & 0.50 & 0.00 & 1.00 \\
Mother's Occupation & & & & \\
$\quad$ Professional, Technical, Managerial & 0.03 & 0.18 & 0.00 & 1.00 \\
$\quad$ Clerical & 0.01 & 0.11 & 0.00 & 1.00 \\
$\quad$ Sales & 0.11 & 0.32 & 0.00 & 1.00 \\
$\quad$ Agriculture & 0.28 & 0.45 & 0.00 & 1.00 \\
$\quad$ Household and Domestic & 0.01 & 0.11 & 0.00 & 1.00 \\
$\quad$ Services & 0.04 & 0.20 & 0.00 & 1.00 \\
$\quad$ Manual & 0.06 & 0.24 & 0.00 & 1.00 \\
Household Wealth & 31.82 & 24.36 & 0.00 & 100.00 \\
Mother's Education & & & & \\
$\quad$ Primary & 0.33 & 0.47 & 0.00 & 1.00 \\
$\quad$ Secondary & 0.26 & 0.44 & 0.00 & 1.00 \\
$\quad$ Higher & 0.05 & 0.22 & 0.00 & 1.00 \\
Urban Residence & 0.37 & 0.48 & 0.00 & 1.00 \\
Mother's Age & 0.15 & 0.36 & 0.00 & 1.00 \\
Female Household Head & 28.35 & 17.14 & 0.00 & 59.00 \\
Child's Age & 0.51 & 0.50 & 0.00 & 1.00 \\
Male & 6.86 & 3.57 & 2.00 & 36.00 \\
Household Size & & & &
\end{tabular}




\section{References}

Abbi, Rita, Parul Christian, Sunder Gujral, and Tara Gopaldas. 1991. "The Impact of Maternal Work Status on the Nutrition and Health Status of Children." Food and Nutrition Bulletin 13(1): 20-25.

Acharya, Dev R., Jacqueline S. Bell, Padam Simkhada, Edwin R. Van Teijlingen, and Pramod R. Regmi. 2010. "Women's Autonomy in Household Decision-Making: A Demographic Study in Nepal." Reproductive Health 7(1): 15.

Agarwal, Bina. 2003. "Gender and Land Rights Revisited: Exploring New Prospects via the State, Family and Market." Journal of Agrarian Change 3(1-2): 184-224.

Barclay, Kieron and Mikko Myrskyla. 2016. "Advanced Maternal Age and Offspring Outcomes: Reproductive Aging and Counterbalancing Period Trends." Population and Development Review 42(1): 69-94.

Basu, Alaka Malwade and Kaushik Basu. 1991. “Women's Economic Roles and Child Survival: The Case of India." Health Transition Review 1(1): 83-103.

Bauer, Katherine W., Mary O. Hearst, Kamisha Escoto, Jerica M. Berge, and Dianne NeumarkSztainer. 2012. "Parental Employment and Work-Family Stress: Associations with Family Food Environments." Social Science \& Medicine 75(3): 496-504.

Bhattacharya, Prabir C. 2006. "Economic Development, Gender Inequality, and Demographic Outcomes: Evidence from India." Population and Development Review 32:263-291.

Berman, Peter, Jennifer Zeitlin, Prodipto Roy, and Sarojini Khumtakar. 1997. "Does Maternal Employment Augment Spending for Children's Health Care? A Test from Haryana, India." Health Transition Review 7(2): 187-204.

Blackwell, Debra L., Mark D. Hayward, and Eileen Crimmins. 2001. "Does Childhood Health Affect Chronic Morbidity Later in Life?" Social Science \& Medicine 52: 1269-1284.

Blumberg, Rae Lesser. 1988. "Income Under Female Versus Male Control: Hypotheses from a Theory of Gender Stratification and Data from the Third World." Journal of Family Issues 9: 51-84.

Boehmer, Ulrike and John B. Williamson. 1996. "The Impact of Women's Status on Infant Mortality Rate: A Cross-National Analysis." Social Indicators Research 37:333-360.

Bollen, Kenneth A., Jennifer L. Glanville, and Guy Stecklov. 2001. "Socioeconomic Status and Class in Studies of Fertility and Health in Developing Countries." Annual Review of Sociology 27:153-185.

Burroway, Rebekah. 2015. "Women's Rights Save Lives: A Cross-National Analysis of Infant and Child Mortality and Women's Access to Land, Property, and Loans in Developing Countries." Sociology of Development 1(4): 418-441.

Burroway, Rebekah. 2016. "Empowering Women, Strengthening Children: A Multi-Level Analysis of Gender Inequality and Child Malnutrition in Developing Countries." Advances in Gender Research 22: 117-142.

Buvinic, Mayra and Geeta Rao Gupta. 1997. "Female-Headed Households and Female Maintained Developing Countries?" Economic Development and Cultural Change 45(2): 259-280.

Carter, Marion W. 2004. "Gender and Community Context: An Analysis of Husbands' Household Authority in Rural Guatemala." Sociological Forum 19: 633-652.

Coburn, Carolyn, Michael Restivo, and John M. Shandra. 2015. "The African Development Bank and Women's Health: A Cross-National Analysis of Structural Adjustment and Maternal Mortality." Social Science Research 51: 307-321. 
Corsi, Daniel J., Melissa Neuman, Jocelyn E. Finlay, and S.V. Subramanian. 2012. "Demographic and Health Surveys: A Profile." International Journal of Epidemiology 41(6): 1602-1613.

Dharmalingam, A. and S. Philip Morgan. 1996. "Women's Work, Autonomy, and Birth Control: Evidence from Two South India Villages." Population Studies 50:187-201.

Desai, Sonalde, and Kiersten Johnson. 2005. "Women's Decisionmaking and Child Health: Familial and Social Hierarchies." Pp. 55-68 in A Focus on Gender: Collected Papers on Gender Using DHS Data, edited by Sunita Kishor. Calverton, MD: ORC Macro.

Diiro, Gracious M., Abdoul G. Sam, and David Kraybill. 2016. "Heterogeneous Effects of Maternal Labor Market Participation on the Nutritional Status of Children: Empirical Evidence from Rural India." Child Indicators Research: 1-24.

Drovandi, Simona and Silvana Salvini. 2004. "Women's Autonomy and Demographic Behaviour." Population Review 43(2): 1-31.

Duflo, Esther. 2012. "Women Empowerment and Economic Development." Journal of Economic Literature 50(4): 1051-1079.

Ellis, Frank. 2000. Rural Livelihoods and Diversity in Developing Countries. Oxford: Oxford University Press.

Enders, Craig K. and Davood Tofighi. 2007. "Centering Predictor Variables in Cross-Sectional Multi-Level Models: A New Look at an Old Issue." Psychological Methods 12: 121-138.

Frongillo, Jr., Edward A., Mercedes de Onis, and Kathleen M.P. Hanson. 1997. "Socioeconomic and Demographic Factors are Associated with Worldwide Patterns of Stunting and Wasting of Children." Journal of Nutrition 127: 2302-2309.

Ghuman, Sharon J., Helen J. Lee, and Herbert L. Smith. 2006. "Measurement of Women's Autonomy According to Women and Their Husbands: Results from Five Asian Countries." Social Science Research 35: 1-28.

Glick, Peter. 2002. "Women's Employment and its Relation to Children's Health and Schooling in Developing Countries: Conceptual Links, Empirical Evidence, and Policies." Cornell Food and Nutrition Policy Program Working Paper 131. Ithaca, NY: Cornell University.

Glick, Peter, and David E. Sahn. 1998. "Maternal Labour Supply and Child Nutrition in West Africa." Oxford Bulletin of Economics and Statistics 60(3): 325-355.

Givens, Jennifer E. and Andrew K. Jorgenson. 2013. "Individual Environmental Concern in the World Polity: A Multilevel Analysis." Social Science Research 42: 418-431.

Gummerson, Elizabeth and Daniel Schneider. 2013. "Eat, Drink, Man, Woman: Gender, Income Share, and Household Expenditure in South Africa." Social Forces 91(3): 813-836.

Guo, Guang and Hongxin Zhao. 2000. "Multilevel Modeling for Binary Data." Annual Review of Sociology 26:441-462

Hashemi, Syed M., Sidney Ruth Schuler, and Ann P. Riley. 1996. "Rural Credit Programs and Women's Empowerment in Bangladesh." World Development 24(4): 635-653.

Heaton, Tim B., Tina J. Huntsman, and Dallan F. Flake. 2005a. "The Effects of Status on Women's Autonomy in Bolivia, Peru, and Nicaragua." Population Research and Policy Review 24: 283-300.

Heaton, Tim B., Renata Forste, John P. Hoffmann, and Dallan Flake. 2005b. "Cross-National Variation in Family Influences on Child Health." Social Science \& Medicine 60: 97-108. 
Hoddinott, John, and Lawrence Haddad. 1995. "Does Female Income Share Influence Household Expenditures? Evidence From Cote D'Ivoire." Oxford Bulletin of Economics and Statistics 57(1): 77-96.

IFC. 2013. Investing in Women's Employment: Good for Business, Good for Development. Washington, DC: IFC.

ILO. 2012. Global Employment Trends for Women. Geneva, Switzerland: ILO.

ILO. 2016. Women at Work: Trends 2016. Geneva, Switzerland: ILO.

Imai, Katsushi S., Samuel Kobina Annim, Veena S. Kulkarni, and Raghav Gaiha. 2014.

"Women's Empowerment and Prevalence of Stunted and Underweight Children in Rural India." World Development 62: 88-105.

Jenkins, J. Craig and Stephen J. Scanlan. 2001. "Food Security in Less Developed Countries, 1970 to 1990." American Sociological Review 66: 718-744.

Jones-Smith, J.C., P. Gordon-Larsen, A. Siddiqi, and B.M. Popkin. 2012. "Is the Burden of Overweight Shifting to the Poor Across the Globe? Time Trends Among Women in 39 Low- and Middle-Income Countries (1991-2008). International Journal of Obesity 36: 1114-1120.

Kravdal, Øystein. 2004. "Child Mortality in India: The Community-Level Effect of Education." Population Studies 58(2): 177-192.

Lamontagne, Jessica F., Patrice L. Engle, and Marian F. Zeitlin. 1998. "Maternal Employment, Child Care, and Nutritional Status of 12-18-Month-Old Children in Managua, Nicaragua." Social Science \& Medicine 46(3): 403-414.

LeGrand, Thomas K. and James F. Phillips. 1996. "The Effect of Fertility Reductions on Infant and Child Mortality: Evidence from Matlab in Rural Bangladesh." Population Studies 50: 51-68.

Leslie, Joanne. 1988. "Women's Work and Child Malnutrition in the Third World." World Development 16(11): 1341-1362.

Macro. 2009. "Demographic and Health Surveys." ICF Macro. Available at http://www.measuredhs.com/.

Maddah, Mohsen, Zahra Mohtasham-Amiri, Arash Rashidi, and Majid Karandish. 2007. "Height and Weight of Urban Preschool Children in Relation to Their Mothers' Educational Levels and Employment Status in Rasht City, Northern Iran." Maternal \& Child Nutrition 3(1): 52-57.

Magadi, Monica A. 2011. "Household and Community HIV/AIDS Status and Child Malnutrition in Sub-Saharan Africa: Evidence from the Demograhic and Health Surveys." Social Science \& Medicine 73: 436-446.

Malhotra, Anju and Mark Mather. 1997. "Do Schooling and Work Empower Women in Developing Countries? Gender and Domestic Decisions in Sri Lanka." Sociological Forum 12: 599-630.

Malhotra, Anju, and Sidney Ruth Schuler. 2005. "Women's Empowerment as a Variable in International Development.” Pp. 71-88 in Measuring Empowerment: Cross-Disciplinary Perspectives, edited by Deepa Narayan.Washington, DC: World Bank.

Martorell, Reynaldo, L. Kettel Khan, and Dirk G. Schroeder. 1994. "Reversibility of Stunting: Epidemiological Findings in Children from Developing Countries." European Journal of Clinical Nutrition 48: S45-57.

McGuire, Judith S., and Barry M. Popkin. 1990. "Helping Women Improve Nutrition in the Developing World." World Bank Technical Paper 114. Washington, DC: World Bank. 
McTavish, Sarah, Spencer Moore, Sam Harper, and John Lynch. 2010. "National Female Literacy, Individual Socio-Economic Status, and Maternal Health Care Use in SubSaharan Africa." Social Science \& Medicine 71: 1958-1963.

Mehra, Rekha and Sarah Gammage. 1999. “Trends, Countertrends, and Gaps in Women's Employment." World Development 27(3): 533-550.

Moghadam, Valentine M. 1999. "Gender and Globalization: Female Labor and Women's Mobilization." Journal of World-Systems Research 2: 367-388.

Montgomery, Mark, Michele Gragnolati, Kathleen Burke, and Edmundo Paredes. 2000. "Measuring Living Standards With Proxy Variables." Demography 37(2): 155-74.

Morrill, Melinda Sandler. 2011. "The Effects of Maternal Employment on the Health of SchoolAge Children." Journal of Health Economics 30(2): 240-257.

Morrissey, Taryn W. 2013. "Trajectories of Growth in Body Mass Index Across Childhood: Associations with Maternal and Paternal Employment." Social Science \& Medicine 95: 60-68.

Mugo, Mercy G. 2012. "Policy Brief: Impact of Parental Socioeconomic Status on Child Health Outcomes in Kenya." African Development Review 24(4): 342-357.

Nussbaum, Martha C. 2003. "Women's Education: A Global Challenge." Signs: Journal of Women in Culture and Society 29: 325-355.

Oropesa, R.S. 1997. "Development and Marital Power in Mexico." Social Forces 75: 1291-1317. Pomeroy, Carlton and Steve Jacob. 2004. "Mangos to Manufacturing: Uneven Development and Its Impact on Social Well-Being in the Dominican Republic." Social Indicators Research 65(1): 73-107.

Popkin, Barry M. 1999. "Urbanization, Lifestyle Changes and the Nutrition Transition." World Development 27(11): 1905-1916.

Quisumbing, Agnes R., ed. 2003. Household Decisions, Gender, and Development: A Synthesis of Recent Research. Washington, DC: International Food Policy Research Institute.

Quisumbing, Agnes R., Kelly Hallman, and Marie T. Ruel. 2007. "Maquiladoras and Market Mamas: Women's Work and Childcare in Guatemala City and Accra." The Journal of Development Studies 43(3): 420-455.

Quisumbing, Agnes R., Ruth Meinzen-Dick, Terri L. Raney, André Croppenstedt, Julia A. Behrman, and Amber Peterman, eds. 2014. Gender in Agriculture: Closing the Knowledge Gap. New York: Springer.

Raudenbush, Stephen W. and Anthony S. Bryk. 2002. Hierarchical Linear Models: Applications and Data Analysis Methods, 2nd edition. Thousand Oaks, CA: Sage Publications.

Raudenbush, Stephen W., Anthony S. Bryk, Yuk Fai Cheong, and Richard Congdon. 2004. HLM 6: Hierarchical Linear and Nonlinear Modeling. Lincolnwood, IL: Scientific Software International.

Richards, Esther, Sally Theobald, Asha George, Julia C. Kim, Christiane Rudert, Kate Jehan, and Rachel Tolhurst. 2013. "Going Beyond the Surface: Gendered Intra-Household Bargaining as a Social Determinant of Child Health and Nutrition in Low and Middle Income Countries." Social Science \& Medicine 95: 24-33.

Sen, Amartya 1999. Development as Freedom. New York: Anchor Books.

Shroff, Monal, Paula Griffiths, Linda Adair, Chirayath Suchindran, and Margaret Bentley. 2009. "Maternal Autonomy is Inversely Related to Child Stunting in Andhra Pradesh, India." Maternal \& Child Nutrition 5(1): 64-74. 
Shuhaimi, Farhanah, and Naleena Devi Muniandy. 2012. "The Association of Maternal Employment Status on Nutritional Status Among Children in Selected Kindergartens in Selangor, Malaysia." Asian Journal of Clinical Nutrition 4(2): 53-66.

Smith, Lisa C., Usha Ramakrishnan, Aida Ndiaye, Lawrence Haddad, and Reynaldo Martorell. 2003. The Importance of Women's Status for Child Nutrition in Developing Countries. Washington, DC: International Food Policy Research Institute.

Sutcliffe, Alastair G., Jacqueline Barnes, Jay Belsky, Julian Gardiner, and Edward Melhuish. 2012. "The Health and Development of Children Born to Older Mothers in the United Kingdom: Observational Study Using Longitudinal Cohort Data." British Medical Journal 345. doi: http://dx.doi.org/10.1136/bmj.e5116.

Thomas, Duncan. 1990. "Intra-household Resource Allocation: An Inferential Approach." Journal of Human Resources 25(4): 635-64.

Thomas, Duncan, John Strauss, and Maria-Helena Henriques. 1990. "How Does Mother's Education Affect Child Height." The Journal of Human Resources 26: 183-211.

Toyama, N., S. Wakai, Y. Nakamura, and Andryansyah Arifin. 2001. "Mother's Working Status and Nutritional Status of Children Under the Age of 5 in Urban Low-Income Community, Surabaya, Indonesia." Journal of Tropical Pediatrics 47(3): 179-181.

Treas, Judith and Tsui-o Tai. 2012. "Apron Strings of Working Mothers: Maternal Employment and Housework in Cross-National Perspective.” Social Science Research 41: 833-842.

Ukwuani, Festus A. and Chirayath M. Suchindran. 2003. "Implications of Women's Work for Child Nutritional Status in Sub-Saharan Africa: A Case Study of Nigeria." Social Science \& Medicine 56(10): 2109-2121.

UNICEF. 2007. State of the World's Children 2008. New York: United Nations Children's Fund.

UNICEF. 2015. Levels and Trends in Child Malnutrition: UNICEF - WHO - The World Bank Joint Malnutrition Estimates. New York: United Nations Children's Fund, World Health Organization, and World Bank Group.

Vaessen, Martin, Mamadou Thiam, and Thanh Lê. 2005. "Chapter XXII The Demographic and Health Surveys." United Nations Statistical Division, United Nations Department of Economic and Social Affairs.

Verick, Sher. 2014. "Female Labor Force Participation in Developing Countries." IZA World of Labor 87: 1-10.

Wamani, Henry, Anne Nordrehaug Åstrøm, Stefan Peterson, James K. Tumwine, and Thorkild Tylleskär. 2007. "Boys are More Stunted Than Girls in Sub-Saharan Africa: A MetaAnalysis of 16 Demographic and Health Surveys." BMC Pediatrics 7(1): 17.

Wills, Jeremiah B. and Jonathan R. Brauer. 2012. "Have Children Adapted to Their Mothers Working, or Was Adaptation Unneccessary? Cohort Effects and the Relationship Between Maternal Employment and Child Well-Being." Social Science Research 41: 425-443.

World Bank. 2010. "World Development Indicators." Available at http://databank.worldbank.org.

World Bank. 2011. World Development Report 2012: Gender Equality and Development. Washington, DC: World Bank

World Bank. 2012. World Development Report 2013: Jobs. Geneva, Switzerland: World Bank

World Bank. 2014. Gender at Work: A Companion to the World Development Report on Jobs. Geneva, Switzerland: World Bank.

WHO. 2006. WHO Child Growth Standards. Geneva, Switzerland: WHO. 
Young, Frank W. 2001. "Structural Pluralism and Life Expectancy in Less-Developed Countries: The Role of Women's Status." Social Indicators Research 55: 223-240. 